LEARNING IN THE FAST LANE 



\section{Learning in the \\ Fast Lane}

\section{The Past, Present, and Future of}

Advanced Placement

Chester E. Finn, Jr., and

Andrew E. Scanlan 
Copyright ( $\odot 2019$ by Princeton University Press

Requests for permission to reproduce material from this work should be sent to permissions@press.princeton.edu

Published by Princeton University Press

41 William Street, Princeton, New Jersey 08540

6 Oxford Street, Woodstock, Oxfordshire OX20 ITR

press.princeton.edu

All Rights Reserved

ISBN 978-0-691-17872-1

Library of Congress Control Number: 2019942780

British Library Cataloging-in-Publication Data is available

Editorial: Peter Dougherty and Alena Chekanov

Production Editorial: Karen Carter

Jacket/Cover Design: Layla Mc Rory

Production: Erin Suydam

Publicity: Tayler Lord and Kate Farquhar-Thomson

This book has been composed in Adobe Text and Gotham

Printed on acid-free paper. $\infty$

Printed in the United States of America

$1098876 \begin{array}{lllll}10 & 9 & 3 & 2 & 1\end{array}$ 
With gratitude and love for the families that nudged us into faster lanes, and have done their best to keep us there. 
